Article

\title{
Comparative Study between Current Practices on Cassava Drying by Small-Size Enterprises in Africa
}

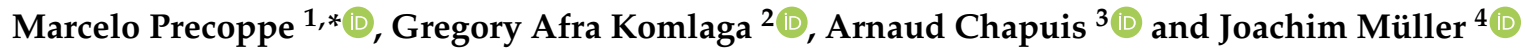 \\ 1 Natural Resources Institute, University of Greenwich, Central Avenue, Chatham Maritime, \\ Kent ME4 4TB, UK \\ 2 Food Research Institute, Council for Scientific and Industrial Research, Gulf Street Adamafio Link, \\ Accra GA-107-2878, Ghana; gakomlaga@foodresearchgh.org \\ 3 CIRAD, UMR Qualisud, 34398 Montpellier, France; arnaud.chapuis@cirad.fr \\ 4 Tropics and Subtropics Group, Institute of Agricultural Engineering, University of Hohenheim, \\ Garbenstraße 9, 70599 Stuttgart, Germany; j.mueller@uni-hohenheim.de \\ * Correspondence: m.precoppe@gre.ac.uk; Tel.: +44-1634-883-239
}

Received: 15 October 2020; Accepted: 4 November 2020; Published: 6 November 2020

Featured Application: This work compares two different dryers commonly used for cassava processing in Africa, concluding that a pneumatic dryer is a better choice of equipment than a fixed-bed dryer. The findings can be used to guide future research on improving those dryers and lead rural development projects in the dissemination of the most suitable drying technology.

\begin{abstract}
Small-size enterprises drying cassava in Africa mostly use fixed-bed dryers or pneumatic dryers. The objective of this study was to determine which of those two dryers is the best choice for this operation. Energy performance, product quality and costs were measured and analysed using a comparative experiment design. Each dryer was considered as a treatment and experiments were performed in quintuplicate at a cassava processing small-size enterprise in Ghana. The energy performance of the pneumatic dryer was superior because of the better contact between the cassava grits and the drying air, resulting in greater heat and mass transfer. The cassava flour obtained from the fixed-bed dryer had a higher Whiteness Index, but the same level of lightness, and the staff responsible for managing product quality was not able to visually distinguish them. As a result of the pneumatic dryer's better energy performance, its operating cost was lower. The capital cost of this dryer was higher, but to recover the additional investment only 194 days of operation were needed. Therefore, it was concluded that pneumatic dryers are a better choice of equipment for cassava drying by small-size enterprises in Africa.
\end{abstract}

Keywords: convection dryer; pneumatic dryer; flash dryer; fixed-bed dryer; flatbed dryer; energy efficiency; product quality; costs

\section{Introduction}

Cassava (Manihot esculenta Crantz) is a perennial root crop native to South America [1] but is nowadays cultivated throughout the humid tropics [2]. The roots are rich in starch and are the main source of calories for many people living in sub-Saharan Africa [3]. However, two days after being harvested, the cassava roots become unsuitable for human consumption and consequently, post-harvest losses are high [4]. To extend cassava shelf-life, the most common practice is to process the roots into flour; a dried product that can be used later as the basis for many dishes [2].

To process cassava into flour, the roots are peeled, grated, pressed, pulverized, dried and milled [4]. Large-scale cassava processing equipment is nowadays efficient because it has been subject 
to development for a long time [5]. In contrast, small-scale cassava equipment, of a size suitable for small-size enterprises, is in the early stages of development [6] and have variable levels of efficiency [7].

Cassava processing enterprises in Africa are mostly of small size [3]. A few large cassava processing industries, using state-of-the-art dryers, operate in West and South Africa. However, they produce cassava starch for industrial use and do not compete with the small-size enterprise producing cassava flour for domestic consumption [2]. For the small-size enterprise, processing equipment should have low capital and operating costs, should be easy to build and should be simple to operate [8]. Fixed-bed dryers and pneumatic dryers, also known as flash dryer, have those characteristics and therefore are the main types of dryers used by small-size enterprises in Africa to produce cassava flour [2]. Pneumatic dryers are more efficient than fixed-bed dryers when drying solids that can be transported pneumatically [9] but, for cassava processing by small-size enterprises in Africa, fixed-bed dryers are more common because of its greater versatility, simplicity and lower capital cost [10]. However, there has been no study determining which of those two types of dryers is the best choice of equipment for this operation.

Table 1 shows the main differences and similarities between fixed-bed dryers and pneumatic dryers. Fixed-bed dryers, also known as flatbed dryer or bin dryer, are batch operated [11], thus the wet solid is loaded to the dryer and kept until it reaches the desired moisture level [12]. This kind of dryer usually consists of simple containers with a perforated screen in the middle, as a false floor, where the solid to be dried is placed [13]. Fixed-bed dryers use hot air as a drying medium and thus is a convection dryer. The heated air is forced into a plenum chamber below the perforated screen, passing through the orifices and then through the solid [14]. In this kind of dryer, heat is usually generated by a burner, fuelled by kerosene, diesel or gas. Forced airflow is produced by a fan, powered by an electric motor or a combustion engine [15]. While fixed-bed dryers have the advantage of being simple in design, construction and operation [12], its shape and configuration inevitably create an uneven air distribution that results in non-uniform drying [16]. Several solutions have been tested to improve this [17], but the most common practice is still to manually move the solid being dried at regular intervals [18], a practice that increases the work drudgery and jeopardizes equipment energy performance [19]. In fixed-bed dryers, as the solid becomes drier the temperature of the air at the outlet increases, and its relative humidity drops. This allows for air recirculation, and this energy-saving method has been successfully applied in this kind of equipment [20]. However, for cassava drying, because the material is rich in starch, air recirculation must be approached with caution. If a proper heat recovery unit is not used, dust explosion is likely to occur [21].

Table 1. Major characteristics of fixed-bed dryer and pneumatic dryers, where plus signs denote levels, ranging from one plus sign $(+)$ to five plus signs $(+++++)$.

\begin{tabular}{cllll}
\hline & \multicolumn{2}{c}{ Fixed-Bed } & \multicolumn{2}{c}{ Pneumatic } \\
\hline Drying air temperature & ++ & {$[20]$} & +++++ & {$[22]$} \\
Solid temperature & +++ & {$[20]$} & ++ & {$[22]$} \\
Dried product uniformity & + & {$[17]$} & ++ & {$[23]$} \\
Capital costs & ++ & {$[24]$} & +++ & {$[25]$} \\
Maintenance cost & ++ & {$[17]$} & ++ & {$[25]$} \\
Versatility & +++++ & {$[24]$} & +++ & {$[26]$} \\
Simplicity & ++++ & {$[27]$} & ++++ & {$[23]$} \\
Energy efficiency & + & {$[24]$} & +++++ & {$[28]$} \\
\hline
\end{tabular}

Values inside square brackets denotes sources of the data presented.

Like fixed-bed dryers, pneumatic dryers are also a convection dryer but continuously operated. In this dryer wet solids are constantly loaded at the feeder and dried solids are constantly unloaded at the outlet [12]. This kind of equipment also uses a burner to produce heat, and a fan to generate forced airflow. However, on pneumatic dryers, drying occurs at the drying duct while the solids are being pneumatically transported. At the end of the drying duct, one or more cyclones are installed for 
separating the solids from the drying air. Like fixed-bed dryers, pneumatic dryers use hot air to supply the heat for moisture evaporation and to transport it away from the solid being dried [11]. However, at the pneumatic dryers, air velocity in the drying duct is high enough to make the solid suspend and be conveyed pneumatically [9]. This improves greatly the contact between solid and hot air, enhancing heat and mass transfer and consequently increasing the water evaporation rate. The higher evaporation rate, and the consequent short drying time, allows using elevated air temperatures. This results in superior levels of energy efficiency [7], without overheating the solid, or jeopardizing product quality [29].

Drying is an energy-intense operation and the evaluation of the energy performance of a drying system is a fundamental step towards its improvement [30]. Significant improvements in the energy performance of a dryer can be achieved by simply evaluating it, and subsequently making the necessary amendments [31]. To evaluate the energy performance of a dryer various indices can be used, but energy efficiency and specific heat consumption are the most useful ones [30].

The energy performance of a dryer is an important aspect to be considered when determining the best choice of drying equipment. One reason is that it has a direct implication on cost. However, the type of dryer and its operating conditions are also important because they have a direct implication on the product quality [32], and product quality determines consumers' acceptance or rejection [33]. Consumers judge the quality of food mostly by looking at its appearance [34] and among the various properties of appearance, colour is the one with by far greater influence in their decision [35]. This is particularly true for dried products [36], and for dried cassava products the critical colour parameter is whiteness [5].

While the quality of the final product is an important aspect to be considered when determining which is the best choice of drying equipment, the cost is another, as it has a direct implication on profits [37]. However, costs and product quality are often competing factors [38] and, therefore, it is fundamental to find a favourable combination between them [37]. The objective of this study was, therefore, to evaluate and compare the energy performance, product quality and costs of the two most common dryer types used for cassava drying by small-size enterprises in Africa. The evaluation provided guidelines on how to improve those dryers and the comparison determined which of the equipment is best suited for the small-scale operation, a question that cassava processors, policymakers and researchers working on rural development are frequently confronted with.

\section{Materials and Methods}

\subsection{Experimental Procedure}

The study was performed as a survey of the current practices of a small-size cassava processing enterprise located at the town of Abura Dunkwa in the Central Region of south Ghana ( $5^{\circ} 19^{\prime} 58^{\prime \prime}$ north; $1^{\circ} 10^{\prime} 13^{\prime \prime}$ west). This cassava processing enterprise grows its cassava but also buys it from other growers in the region. The survey followed the usual material preparation and drying procedure of the cassava processing enterprise, and no interventions were made other than collecting samples and measuring drying conditions. This enterprise uses a fixed-bed dryer and a pneumatic dryer to produce cassava flour. The final product is shipped in bulk to Accra and sold to wholesalers, who evaluate the flour appearance and moisture content to assess quality. The survey used a comparative experimental design, with 5 replicates. Each dryer type was considered as a treatment and data collection was conducted over 10 consecutive days, in series, one dryer type per day. The order in which each dryer was used was randomized.

The steps used to process the cassava root into flour are shown in Figure 1. At the processing enterprise locally grown, freshly harvested, cassava roots were peeled by hand, washed manually and turned into a mash using a mechanical grater. The mash was subsequently dewatered with a screw operated press and then the resulting press-cake was pulverized into wet cassava grits using another mechanical grater. 


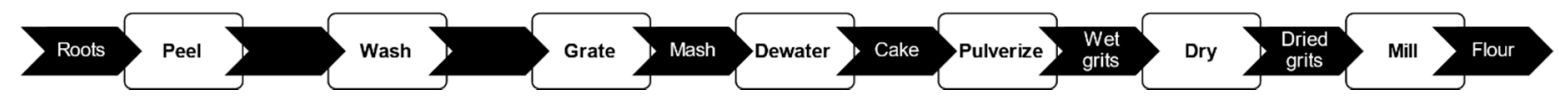

Figure 1. Steps used to process cassava root into flour.

When the fixed-bed dryer was used, the equipment was loaded with $500 \mathrm{~kg}$ of wet cassava grits without preheating. The wet grits were spread over the perforated screen forming a $0.15 \mathrm{~m}$ thick layer. Aiming to improve uniformity, after $3 \mathrm{~h}$ of drying, the operator manually turned and shifted the cassava grits with a wooden shovel. Drying lasted for a total of $6 \mathrm{~h}$. During the drying process, the temperature of the drying air was thermostatically controlled using a temperature sensor located at the dryer inlet. The thermostat was set to $90{ }^{\circ} \mathrm{C}$ and kept at this value.

When the pneumatic dryer was used, it was preheated for $0.5 \mathrm{~h}$ before being loaded with wet cassava grits. Once loading started, it continued uninterrupted for $7.5 \mathrm{~h}$. In this period, a total of approximately $500 \mathrm{~kg}$ of wet cassava grits were fed to the dryer. Drying air temperature was thermostatically controlled using a temperature sensor located at the dryer inlet, placed before the feeding point. The thermostat was set to $220^{\circ} \mathrm{C}$ and kept at this value.

The fixed-bed dryer was locally manufactured, built in a rectangular shape, $2.54 \mathrm{~m}$ by $2.45 \mathrm{~m}$ with a height of $0.85 \mathrm{~m}$, as illustrated in Figure 2a. The perforated screen was located approximately in the middle of its height and was inclined by an angle of $8^{\circ}$ to facilitate unloading. The equipment was constructed using stainless steel and was thermally insulated with a $50 \mathrm{~mm}$ thick mineral wool, shielded by aluminium sheeting. Air was heated by a heating unit comprising a 70-kW diesel burner and a heat exchanger. Airflow was forced by a radial blower powered by a $5.2 \mathrm{~kW}$ three-phase electric motor. The pneumatic dryer was also locally manufactured. However, as part of a capacity-building activity of a rural development project, in which equipment manufacturers in Ghana learned how to design, dimension and build small-scale pneumatic dryers for cassava processing. The equipment was constructed using stainless steel and was thermally insulated with a $50 \mathrm{~mm}$ thick mineral wool, shielded with aluminium sheeting. The drying duct had a diameter of $0.18 \mathrm{~m}$ and a length of $24.84 \mathrm{~m}$. To reduce the total height of the equipment the drying duct was divided into 7 vertical meandering sections, as illustrated in Figure $2 \mathrm{~b}$. Wet cassava grits were introduced to the drying duct by a feeder powered by a $4.0 \mathrm{~kW}$ three-phase electric geared motor. Airflow was forced by a radial blower powered by a $7.5 \mathrm{~kW}$ three-phase electric motor. The fan was located at the base of the drying duct, just after the feeding point, and thus it operated as a positive pressure conveying system. Air was heated by a heating unit comprising a 70-kW diesel burner and a heat exchanger. On both dryers, the temperature control system simply turns the diesel burner on and off to maintain the temperature at the dryer inlet in the value set at the thermostat. It is a commonly used control system, but it has the limitation of not being able to account for variations on the wet solid moisture content, or on the wet solid feeding rate.

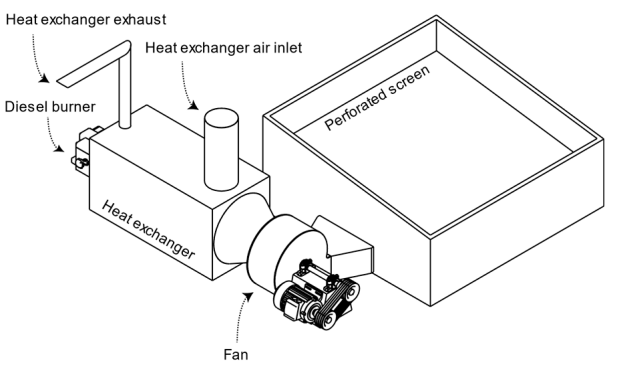

(a)

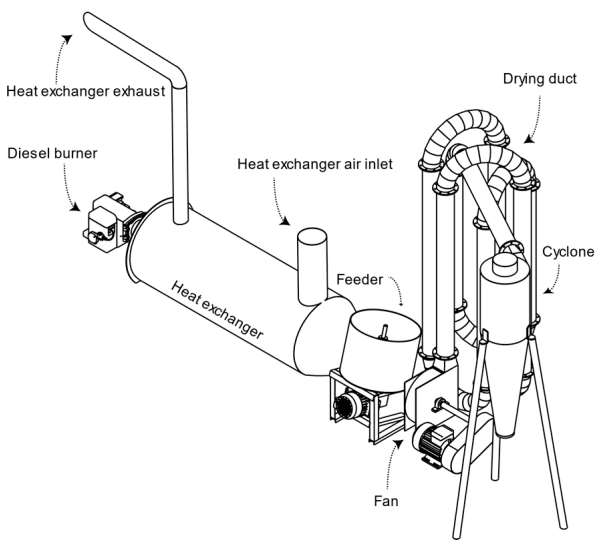

(b)

Figure 2. Isometric view of (a) the fixed-bed dryer and (b) the pneumatic dryer used in this study. 


\subsection{Statistical Analysis}

Statistical analyses were performed with SAS 9.4 (SAS Institute Inc., Cary, NC, USA) software. To determine whether the pairwise difference comparisons were significantly different, Fisher's Least Significant Difference (LSD) was used at a $5 \%$ level of significance $(p<0.05)$. To facilitate inferring if the treatment was significantly different or not, the pairwise treatment comparisons were presented followed by a subscripted letter. In this notation, means with no letter in common are significantly different.

\subsection{Operating Conditions and Energy Performance}

For the fixed-bed dryer, samples of cassava grits were collected just before starting the drying process and at the end of it. Both, wet and dried samples were collected following a three by three grid pattern, as shown in Figure 3a. For the pneumatic dryer, samples of wet and dried cassava grits were collected at the dryer's feeder, and at the cyclone's solid outlet (Figure 3b), respectively, at 0.75 -h intervals. At this dryer, sample collection started only after a steady-state condition was achieved, determined by observing the temperature, $T_{\mathrm{ex}}\left({ }^{\circ} \mathrm{C}\right)$, and relative humidity, $\Psi_{\mathrm{ex}}\left(\%_{\mathrm{rh}}\right)$, trends at the cyclone air outlet, measured with a digital humidity-temperature probe (HC2A-S3, Rotronic, Bassersdorf, Switzerland). On average, a steady-state condition was achieved $0.75 \pm 0.01 \mathrm{~h}$ after the operator has started loading wet grits into the dryer. Samples collected from both dryers were placed on an airtight container and taken to the laboratory of the Food Research Institute (FRI) of the Council for Scientific and Industrial Research in Accra, for moisture content measurement. The moisture content was determined gravimetrically according to the AOAC method 935.29 [39]. Samples were dried for $3 \mathrm{~h}$ at $103 \pm 1{ }^{\circ} \mathrm{C}$, using a convection oven (NE9-112S; Clifton, Weston-super-Mare, UK).

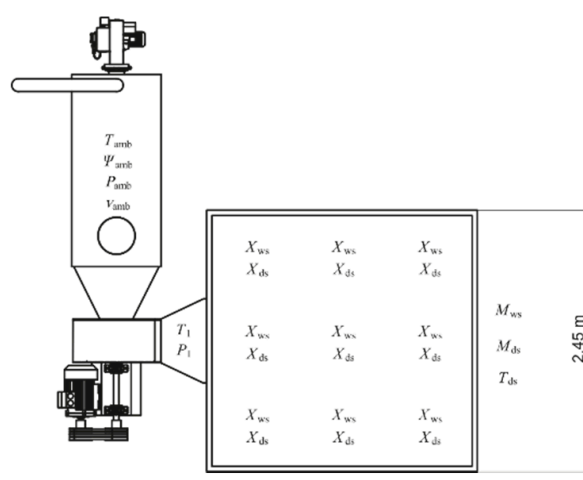

(a)

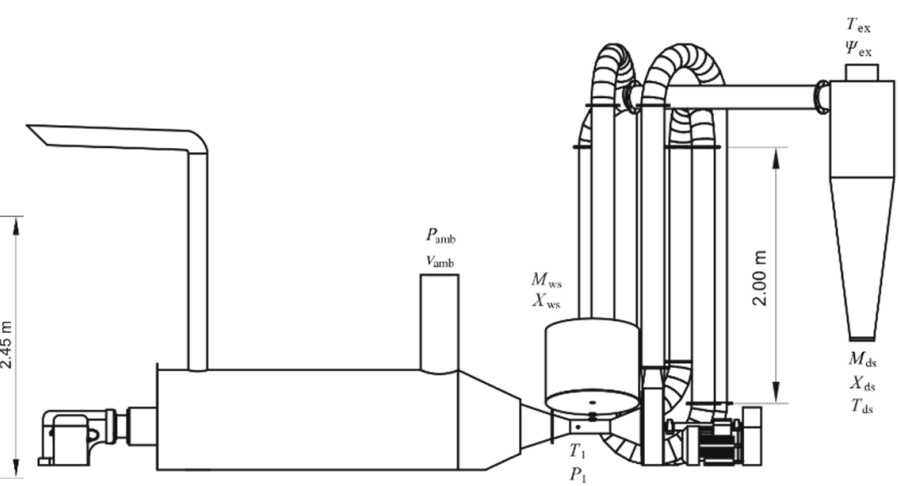

(b)

Figure 3. Measurements made at the dryers: (a) top-view of the fixed-bed dryer and (b) side-view of the pneumatic dryer $(T$, temperature; $\Psi$, relative humidity; $P$, pressure; $v$, air velocity; $\dot{m}$, mass flow rate; $X$, moisture content).

On both dryers, the mass flow rate of the wet cassava grits, $\dot{m}_{\mathrm{ws}}\left(\mathrm{kg} \mathrm{h}^{-1}\right)$, and the mass flow rate of the dried cassava grits, $\dot{m}_{\mathrm{ds}}\left(\mathrm{kg} \mathrm{h}^{-1}\right)$ were measured using a digital balance (AWB120; Avery Weigh-Tronix, Smethwick, UK) and a chronometer. In addition, for the fixed-bed dryer, loading and unloading periods were measured with a chronometer.

On both dryers, the temperature of the dried cassava grits, $T_{\mathrm{ds}}\left({ }^{\circ} \mathrm{C}\right)$ were measured with a resistance thermometer (PT100; Rotronic). For the fixed-bed dryer, measurements were made at the end of the drying process, using a six by six grid pattern. For the pneumatic dryer, temperature was continuously measured and recorded at a 1-min interval using a wireless data-logger (LOG-HC2-RC; Rotronic) with the thermometer placed at the material leaving the cyclone's solid outlet.

On both dryers, the temperature of the air at the dryer inlet, $T_{1}\left({ }^{\circ} \mathrm{C}\right)$, was measured with a resistance thermometer (PT100; Rotronic). For the fixed-bed dryer, the sensor was placed at the duct 
that connects the fan to the dryer bed (Figure 3a). For the pneumatic dryer, the sensor was placed at the duct after the heat exchanger before the feeding point (Figure 3b). On both dryers, the sensors were connected to a wireless data-logger (LOG-HC2-RC; Rotronic) and temperature values were recorded at 1-min interval. Air static-pressure at the dryer inlet, $P_{1}(\mathrm{~Pa})$, was also measured at these locations using a manometer (922; Fluke, Norwich, UK).

Ambient relative humidity, $\Psi_{\mathrm{amb}}(\% \mathrm{rh})$, and ambient air temperature, $T_{\mathrm{amb}}\left({ }^{\circ} \mathrm{C}\right)$, were measured with a digital humidity-temperature probe (HC2A-S3, Rotronic), connected to a wireless data logger (LOG-HC2-RC; Rotronic) recording values at 1-min intervals. The barometric pressure of the ambient air, $P_{\mathrm{amb}}(\mathrm{Pa})$, was measured with a digital barometer (GBP 3300, Greisinger, Regenstauf, Germany) and recorded manually at 30 min intervals.

Air velocity at the heat exchanger inlet, $v_{\mathrm{amb}}\left(\mathrm{m} \mathrm{s}^{-1}\right)$ was measured with a pitot tube connected to a manometer (922; Fluke). Following ASHRAE standard 111-2008 [40], a $1.5 \mathrm{~m}$ long circular duct with a diameter of $0.30 \mathrm{~m}$ was added to the air inlet of the heat exchangers of each dryer and a total of 18 readings were taken across the traverse plane and then averaged.

To assess the uniformity of the airflow across the perforated screen of the fixed-bed dryer, air velocity was measured with a vane anemometer (AFP1, Rotronic) using a six by six grid pattern. Measurements were performed with the dryer loaded, during the first $0.25 \mathrm{~h}$ of the drying operation, using three repetitions.

Psychrometric calculations used the formulas provided by the British Standard [41] and energy performance indices were calculated according to Kudra [30].

The solid mass flow rate on a dry basis, $\dot{m}_{\mathrm{dm}}\left(\mathrm{kg} \mathrm{h}^{-1}\right)$, was obtained using Equation (1):

$$
\dot{m}_{\mathrm{dm}}=\dot{m}_{\mathrm{ws}}-\dot{m}_{\mathrm{ws}}\left(\frac{X_{\mathrm{ws}}}{1+X_{\mathrm{ws}}}\right),
$$

where $\dot{m}_{\mathrm{ws}}\left(\mathrm{kg} \mathrm{h}^{-1}\right)$ is the mass flow rate of the wet cassava grits and $X_{\mathrm{ws}}\left(\mathrm{kg}^{-1}\right)$ is its moisture content on a dry basis.

Heat input rate to the dryer $\left(\dot{Q}_{\text {in }}\right)$ was calculated using Equation (2):

$$
\dot{Q}_{\text {in }}=\dot{m}_{\mathrm{air}}\left(h_{1}-h_{\mathrm{amb}}\right)
$$

where $\dot{m}_{\text {air }}\left(\mathrm{kg} \mathrm{h}^{-1}\right)$ is air mass flow rate on a dry basis, $h_{1}\left(\mathrm{~kJ} \mathrm{~kg}^{-1}\right)$ is the enthalpy of the air at the dryer inlet and $h_{\mathrm{amb}}\left(\mathrm{kJ} \mathrm{kg}^{-1}\right)$ is the enthalpy of the ambient air.

The value for $\dot{m}_{\text {air }}$ was calculated multiplying the air volume flow rate, $\dot{V}_{\text {air }}\left(\mathrm{m}^{3} \mathrm{~h}^{-1}\right)$, to the air density on a dry basis, $\rho_{\text {air }}\left(\mathrm{kg} \mathrm{m}^{-3}\right)$, and the value for $\dot{V}_{\text {air }}$ was calculated multiplying $v_{\text {amb }}$ to the cross-sectional area of the pipe added to the heat exchanger air inlet. The values of $\rho_{\text {air }}$ and $h_{\text {amb }}$ were calculated using $\Psi_{\mathrm{amb}}, T_{\mathrm{amb}}$ and $P_{\mathrm{amb}}$. The value for $h_{1}$ was calculated using $T_{1}$ and $P_{1}$ but because of the elevated temperature at this location, air relative humidity $\left(\Psi_{1}\right)$ was not measured, but calculated from the ambient air conditions.

Water evaporation rate, $\dot{m}_{\mathrm{w}}\left(\mathrm{kg} \mathrm{h}^{-1}\right)$, was calculated using Equation (3):

$$
\dot{m}_{\mathrm{w}}=\dot{m}_{\mathrm{dm}}\left(X_{\mathrm{ws}}-X_{\mathrm{ds}}\right)
$$

where $X_{\mathrm{ds}}\left(\mathrm{kg} \mathrm{kg}^{-1}\right)$ is the dried cassava grits moisture content on a dry basis.

Specific heat consumption, $q_{\mathrm{s}}\left(\mathrm{kJ} \mathrm{kg}^{-1}\right)$, was calculated using Equation (4):

$$
q_{\mathrm{s}}=\frac{\dot{Q}_{\mathrm{in}}}{\dot{m}_{\mathrm{w}}}
$$


Energy efficiency $(\eta)$ was calculated using Equation (5):

$$
\eta=\frac{\dot{Q}_{\mathrm{w}}}{\dot{Q}_{\mathrm{in}}}
$$

where $\dot{Q}_{\mathrm{w}}\left(\mathrm{kJ} \mathrm{h}^{-1}\right)$ is the heat used for moisture evaporation, calculated by multiplying $\dot{m}_{\mathrm{w}}$ to the cassava starch sorption energy, $Q_{\text {st }}\left(\mathrm{kJ} \mathrm{kg}^{-1}\right)$, provided by Al-Muhtaseb et al. [42]. Sorption energy was used instead of the latent heat of vaporization $(\lambda)$, to account for the energy required to overcome capillary forces.

\subsection{Product Colour and Appearance}

According to the usual procedure of the processing enterprise, on each day, the obtained dried cassava grits were milled into flour with a hammermill. Samples from this flour were collected and taken to the FRI laboratory for colour measurements with a colorimeter (CR-410; Konica Minolta, Osaka, Japan). The CIELAB colour space $\left(L^{*}, a^{*}\right.$ and $\left.b^{*}\right)$ with illuminant D65 and $10^{\circ}$ field observer was used, and a granular solid attachment (CR-A50; Konica Minolta) employed, to assure measurement consistency.

In addition to the colour measurements, the flours were also visually assessed as suggested by Jinorose, Devahastin, Blacher and Léonard [34]. At the processing enterprise, the staff responsible for quality control and trading $(n=5)$, were asked to evaluate its overall appearance. This visual assessment followed the general procedure of a central location test [43]. The flours were presented on white plastic plates, each labelled with a three-digit code, and the 10 different products were presented just once, sequentially. The assessment featured a single question regarding the overall product appearance using a 7-point hedonic scale anchored with "dislike extremely" on the left and "like extremely" on the right. Before the evaluation started, the use of the scale was explained and demonstrated.

The whiteness of the cassava flour was evaluated by calculating the Whiteness Index (WI) using the CIE 1964 formula [44]. The whiteness of the cassava flours was also evaluated by analysing its lightness $\left(L^{*}\right)$ and chroma $\left(C^{*}\right)$, as suggested by Judd and Wyszecki [45].

\subsection{Costs Comparison}

For the difference in operating costs, for each dryer, the mass of diesel consumed during drying was measured by weighting the fuel thank with a digital scale (AWB120; Avery Weigh-Tronix). The price of a litre of diesel was obtained from the local filling station. The amount of electricity consumed during drying was measured by installing on each dryer, a digital kilowatt-hour meter (SDM72-D; Eastron, Zhejiang, China) at the mains cable. The price of a kilowatt-hour was obtained from the processing enterprise electricity bill. The number of labour hours was obtained by recording the amount of staff engaged in loading, unloading and operating the dryer. Maintenance costs were obtained from the processing enterprise spending logbook. For the difference in capital costs, as suggested by Crapiste and Rotstein [38], local vendors of agro-processing equipment were contacted.

For each component of the operating costs, the difference between each dryer was calculated in US dollar (USD) per kilogram of dried cassava grit obtained $(\mathrm{kg})$. The number of days of operation needed to repay the higher price of the dryer with lower operating costs, known as payback period (PBP), was calculated using Equation (6):

$$
P B P=\frac{I}{S^{\prime}}
$$

in which $I$ is the capital cost and $S$ is the savings for using the dryer with lower operating costs.

Finally, sensitivity analyses were performed to explore the influence of variations in diesel and electricity prices in the payback period, as suggested by Clark [37]. 


\section{Results and Discussion}

\subsection{Operating Conditions and Energy Performance}

Table 2 shows the operating conditions of the fixed-bed dryer and the pneumatic dryer. Regarding the solid mass flow rate, the throughput of wet cassava grits was $84.1 \pm 4.8 \mathrm{~kg} \mathrm{~h}^{-1}$ for the fixed-bed dryer and was $66.9 \pm 13.9 \mathrm{~kg} \mathrm{~h}^{-1}$ for the pneumatic dryer. The throughput of dried cassava grits was $51.6 \pm 2.9 \mathrm{~kg} \mathrm{~h}^{-1}$ for the fixed-bed dryer and was $41.2 \pm 9.4 \mathrm{~kg} \mathrm{~h}^{-1}$ for the pneumatic dryer. While $\dot{m}_{\mathrm{ws}}, \dot{m}_{\mathrm{ds}}$ and $\dot{m}_{\mathrm{dm}}$ between the dryers were significantly different, the amount of dried cassava grit obtained in one day of operation was not significantly different by LSD test at $5 \%$ level of significance. The fixed-bed dryer was in operation for $6.0 \mathrm{~h}$ per day producing, on average, a total of $307.1 \pm 6.4 \mathrm{~kg}$ while the pneumatic dryer was in operation for $7.5 \mathrm{~h}$ per day producing, on average, a total of $309.2 \pm 70.2 \mathrm{~kg}$. Loading and unloading periods is a known drawback of a batch-operated dryer [12] and on average $0.73 \pm 0.05 \mathrm{~h}$ were needed to load the fixed-bed dryer and $0.77 \pm 0.07 \mathrm{~h}$ to unload it.

Table 2. Operating conditions of a fixed-bed dryer and of a pneumatic dryer used to process cassava in Ghana.

\begin{tabular}{ccccc}
\hline Dryer Type & $\begin{array}{c}\text { Solid Mass Flow Rate } \\
\text { on a Dry Basis }\left(\mathbf{k g ~ h} \mathbf{~ h}^{-\mathbf{1}}\right)\end{array}$ & $\begin{array}{c}\text { Air Temperature } \\
\text { at Dryer Inlet }\left({ }^{\circ} \mathbf{C}\right)\end{array}$ & $\begin{array}{c}\text { Wet Cassava Grits } \\
\text { Moisture Content } \\
\left.\mathbf{( k g ~ k g}^{-1}\right)\end{array}$ & $\begin{array}{c}\text { Dried Cassava } \\
\text { Grits Moisture } \\
\left.\text { Content } \mathbf{~ k g ~ k g ~}^{-\mathbf{1}}\right)\end{array}$ \\
\hline Fixed-bed & $45.0^{\mathrm{a}} \pm 2.6$ & $85.2^{\mathrm{a}} \pm 1.2$ & $0.87^{\mathrm{a}} \pm 0.01$ & $0.15^{\mathrm{a}} \pm 0.02$ \\
Pneumatic & $35.9^{\mathrm{b}} \pm 7.1$ & $226.8^{\mathrm{b}} \pm 14.5$ & $0.86^{\mathrm{a}} \pm 0.05$ & $0.14^{\mathrm{a}} \pm 0.02$ \\
\hline
\end{tabular}

Means with no common superscript letter are significantly different by Fisher's Least Significant Difference test at $5 \%$ level of significance $(\alpha=0.05)$.

The air at the inlet of the dryers is shown in Table 2. Fixed-bed dryers, in general, operate at a lower temperature [46], particularly when compared with pneumatic dryers [47] that, for certain products, can operate at temperatures as high as $700{ }^{\circ} \mathrm{C}$ [48]. The temperature of the drying air has a direct impact on both, the energy performance of the dryer [49] and on the quality of the dried product [32]. In general, better energy performance is obtained with higher drying air temperature [31] and Suherman et al. [50] studying the drying kinetics of cassava starch in pneumatic dryers observed significant improvement in its energy performance by increasing air temperature. However, high drying air temperature can have a detrimental effect on product quality [51], particularly for solids rich in starch [52], and for cassava drying, to avoid starch gelatinization, the temperature of the solid must remain below $64.3^{\circ} \mathrm{C}$ [5]. To estimate solid temperature during drying, the wet-bulb temperature of the drying air can be used [53] and at the fixed-bed dryer, the wet-bulb temperature of the drying air was on average $36.9 \pm 0.2^{\circ} \mathrm{C}$. In contrast, at the pneumatic dryer, the wet-bulb temperature of the drying air was on average $51.9 \pm 3.8^{\circ} \mathrm{C}$. However, at the end of the drying process, temperature of the dried cassava grits at the fixed-bed dryer was on average $50.0 \pm 2.8^{\circ} \mathrm{C}$ and $T_{\mathrm{ds}}$ at the pneumatic dryer was on average $57.2 \pm 5.3^{\circ} \mathrm{C}$. Therefore, despite the higher temperature used in the pneumatic dryer, on both dryers, the solid temperature remained under the gelatinization threshold.

Regarding the moisture content of the wet cassava grits, Table 2 shows no significant differences. In addition, Table 2 shows no significant differences between the two dryers in the moisture content of the dried cassava grits. When comparing the energy performance of two different dryers, it is not necessary to have the same capacity, but it is important to use the same material and assure that initial and final moisture content between the dryers is similar [30]. This is even more important when drying a material that is rich in starch because the energy needed to overcome capillary forces increases exponentially as the solid dries [42].

During the evaluation of the dryers, no significant differences, by LSD test at $5 \%$ level of significance, were observed regarding ambient air temperature, relative humidity and pressure. They were on average $33^{\circ} \mathrm{C}, 62.8 \% \mathrm{rh}$ and $101.0 \mathrm{kPa}$, respectively. 
For both dryers, the same method for mechanically dewatering the cassava mash was used; thus, similar moisture content of the wet cassava grits was obtained. Usually between $20 \%$ and $30 \%$ of the water can be removed by mechanical means [9] and is an important step for energy saving as it consumes substantially less energy than drying with hot air [11]. The values of $X_{\mathrm{ws}}$ shown in Table 2 were within the range reported by Precoppe et al., [54], for wet cassava grits being dried on pneumatic dryers. However, it is important to notice that pneumatic dryers are more frequently used for solids with a moisture content below $0.70 \mathrm{~kg} \mathrm{~kg}^{-1}$ [55]. Nevertheless, moisture content was reduced to a level that is accepted for most markets [5,6,56] and considered stable for long term storage [57].

Table 3 shows the energy performance indices obtained from the fixed-bed dryer and the pneumatic dryer. Regarding the heat input rate, it was significantly higher for the fixed-bed dryer, despite its lower drying air temperature. This is explained by its higher air mass flow rate; $3498 \pm 12 \mathrm{~kg} \mathrm{~h}^{-1}$ compared to $533 \pm 4 \mathrm{~kg} \mathrm{~h}^{-1}$ at the pneumatic dryer.

Table 3. Energy performance indices of a fixed-bed dryer and of a pneumatic dryer used to process cassava in Ghana.

\begin{tabular}{ccccc}
\hline Dryer Type & $\begin{array}{c}\text { Heat Input Rate } \\
\mathbf{( k W )}\end{array}$ & $\begin{array}{c}\text { Water Evaporation } \\
\text { Rate }\left(\mathbf{k g ~ h}^{\mathbf{- 1}}\right)\end{array}$ & $\begin{array}{c}\text { Specific Heat } \\
\left.\text { Consumption } \mathbf{( k J ~ k g} \mathbf{~}^{\mathbf{- 1}}\right)\end{array}$ & $\begin{array}{c}\text { Energy } \\
\text { Efficiency (\%) }\end{array}$ \\
\hline Fixed-bed & $54.0^{\mathrm{a}} \pm 3.2$ & $32.5^{\mathrm{a}} \pm 2.2$ & $6005.4^{\mathrm{a}} \pm 339.1$ & $41.3^{\mathrm{a}} \pm 2.4$ \\
Pneumatic & $29.9^{\mathrm{b}} \pm 2.5$ & $25.6^{\mathrm{b}} \pm 4.8$ & $4316.5^{\mathrm{b}} \pm 690.3$ & $58.7^{\mathrm{b}} \pm 8.7^{\mathrm{b}}$ \\
\hline
\end{tabular}

Means with no common superscript letter are significantly different by Fisher's Least Significant Difference test at $5 \%$ level of significance $(\alpha=0.05)$.

Regarding the evaporation rate, Table 3 shows it was higher in the fixed-bed dryer than in the pneumatic dryer, despite its lower drying air temperature. Water evaporation rate is driven by material properties, material moisture and material quantity, plus the heat input to the dryer and the level of interaction between the material and the drying medium [30]. The fixed-bed dryer had a greater amount of material and a higher heat input rate, explaining its higher evaporation rate.

Regarding specific heat consumption, Table 3 shows it was higher at the fixed-bed dryer, despite its higher evaporation rate. Specific heat consumption of pneumatic dryers in general ranges from $3000 \mathrm{~kJ} \mathrm{~kg}^{-1}$ [9] to $9000 \mathrm{~kJ} \mathrm{~kg}^{-1}$ [58] and for cassava drying with pneumatic dryers Precoppe, Tran, Chapuis, Müller and Abass [54] reported values ranging from $3620 \mathrm{~kJ} \mathrm{~kg}^{-1}$ to $5750 \mathrm{~kJ} \mathrm{~kg}^{-1}$.

Energy efficiency, shown in Table 3, accordingly, was superior for the pneumatic dryer. In general, the energy efficiency of pneumatic dryers usually ranges from $40 \%$ to $75 \%$ [59], and for pneumatic drying of cassava Precoppe, Tran, Chapuis, Müller and Abass [54] reported values ranging from $43 \%$ to $69 \%$. In general, the energy performance of convective dryers is dictated by the heat transfer between solid and the hot air [30], the better the contact between them, the better the energy performance [60]. The superior energy performance of the pneumatic dryer can be explained by the fact that in this dryer the material is suspended in the air, allowing for optimum solid-hot air contact, and thus efficient heat transfer [29].

Overall, the energy performance indices obtained for the pneumatic dryer suggest that the equipment was properly designed. For pneumatic dryers, dimensions have a direct implication on their energy performance [61] and one of the most critical dimension is the length of the drying duct, that must be long enough to allow sufficient time for the particles to dry during the transport [49]. Despite being correctly dimensioned, the equipment was not as efficient as the large-scale pneumatic dryer reported by Sriroth et al. [62]. In addition, it was not as efficient as the medium-scale pneumatic dryers reported by Precoppe, Tran, Chapuis, Müller and Abass [54]. This is explained by the much smaller capacity of the studied pneumatic dryer, designed specifically to be used by small-size enterprises. In small-scale dryers, heat losses are always higher because of their inevitably unfavourable surface-to-volume ratio [63].

Figure 4 shows the uniformity of the air across the perforated screen of the fixed-bed dryer and Figure 5 shows that despite the turning and moving of the cassava grits during drying, moisture 
content of the obtained dried cassava grits was not uniform. Prukwarun et al. [64] studied a dryer of similar shape and observed the same pattern in air velocity across the perforated screen and consequent non-uniformity on the moisture content of the dried solids. Lack of uniformity was also observed in the pneumatic dryer, occurring over the drying time, as shown in Figure 6. Figure 6 also shows that the moisture content of the wet cassava grits loaded to the dryer was relatively uniform, but the same level of uniformity was not observed in the moisture content of the obtained dried cassava grits. This is explained by the uneven temperature of the drying air and the irregular feeding rate of wet cassava grits, depicted in Figure 6.
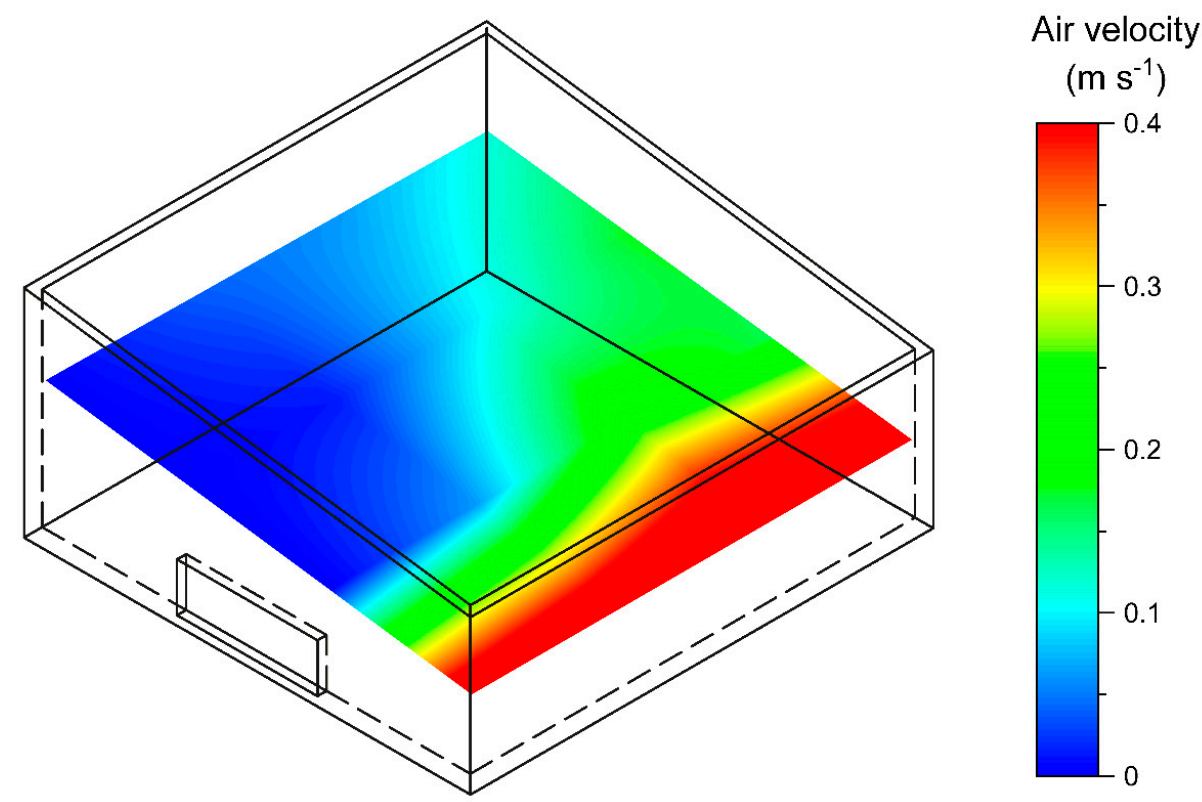

Figure 4. Air velocity across the perforated screen of a small-scale fixed-bed dryer used for cassava processing in Ghana.

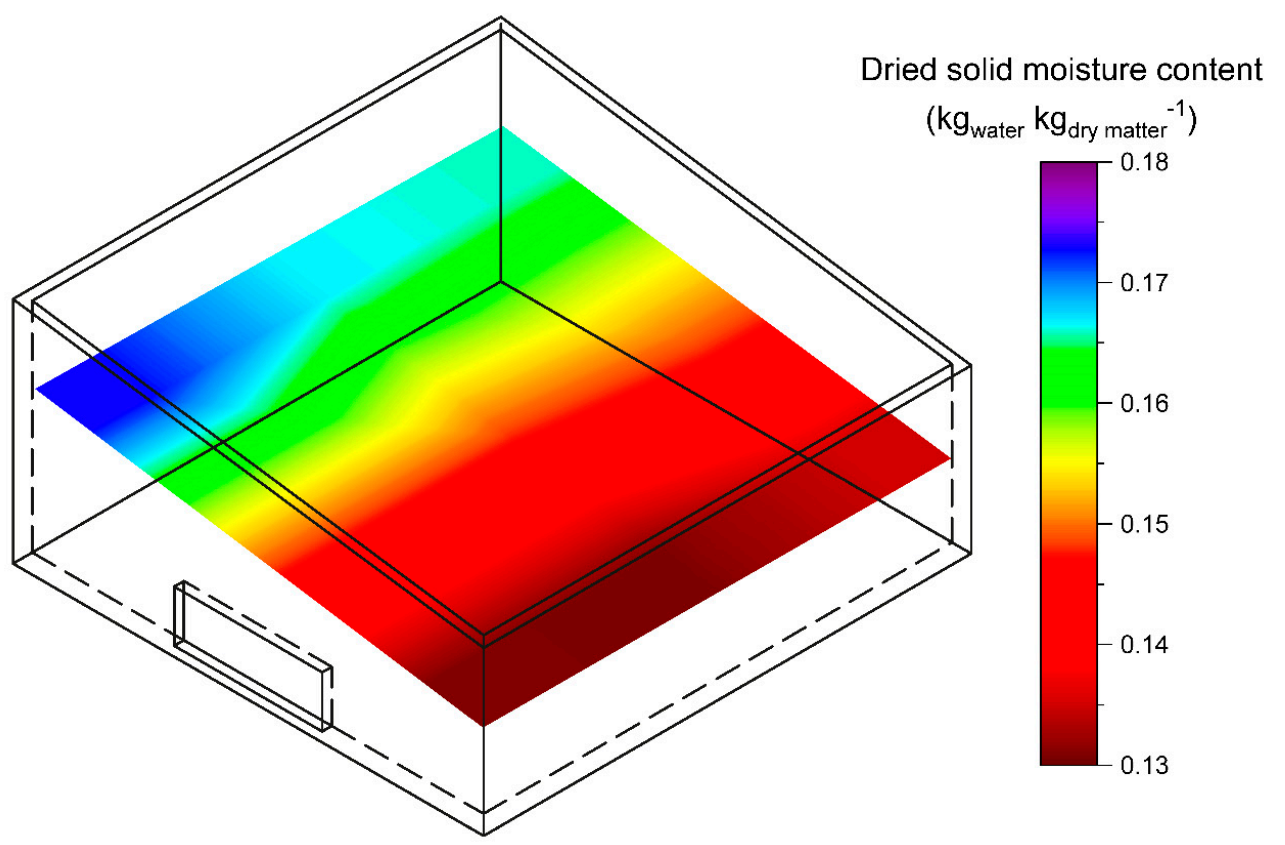

Figure 5. The moisture content of the dried cassava grits across the perforated screen of the fixed-bed dryer. 


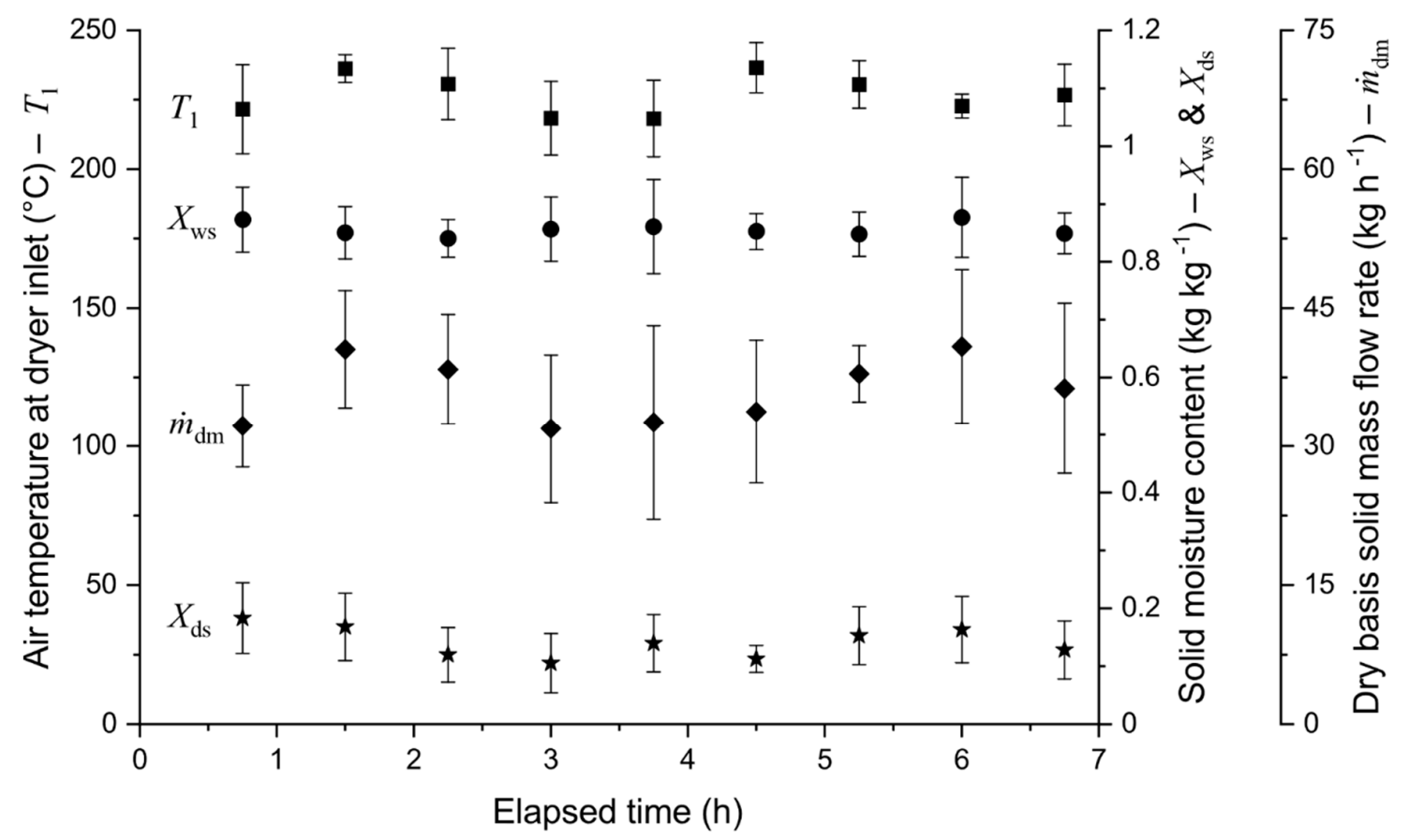

Figure 6. Air temperature at the dryer inlet $(\boldsymbol{\square})$, wet solid moisture content $(\bullet)$, dried solid moisture content $(\star)$, dry basis solid mass flow rate $(\bullet)$ at a pneumatic dryer used for cassava processing in Ghana (error bars shows standard deviation).

For the fixed-bed dryer, several studies have shown ways to improve the uniformity of the moisture content of the dried product $[16,19,65]$. Most of them focused on adding air-guides under the perforated screen to promote a better airflow distribution. While some studies report a high degree of success, the proposed solutions cannot be easily replicated to other dryers. Therefore, another possible way to improve the uniformity would be to add a mechanical device to constantly move and turn the solid during drying. This device could even be designed in a way that enhances the contact between the product and the hot air.

For the pneumatic dryer, uniformity of the dried product can be improved by reducing the fluctuation in the temperature of the drying air and minimizing the variation in the feeding rate of wet solid. The first can be achieved by employing a more responsive temperature control system. In addition to the variation over time shown in Figure 6, Table 2 also shows a discrepancy between drying air temperature and the temperature set at the dryer thermostat, attributed to a low response time of the control system. Furthermore, Block, Lipták and Shinskey [53] suggest placing the temperature sensor at the dryer outlet instead of at the drying inlet, as this provides better control of the drying air temperature and makes it account for variations on the moisture content of the solid being loaded to the dryer. Moreover, variations in the wet solid feeding rate can be reduced with a better design of the feeder. Additional improvements can also be achieved by coupling the temperature control unit to the feeding system, in a way that when the temperature is above the target, the wet solid feeding rate would increase to compensate for it. Conversely, when the temperature is below the target, the feeding rate would decrease to compensate for it. Satpati et al. [66] observed that in pneumatic dryers a control system that can also control the feeding rate not only improves the uniformity of the dried product moisture content but also the energy performance of the dryer.

\subsection{Product Colour and Appearance}

Table 4 shows the appearance parameter from the cassava flour obtained from each dryer. Whiteness Index was significantly higher at the flour from the fixed-bed dryer. This can be attributed to the lower air temperature used in this equipment. 
Table 4. Whiteness Index, lightness, chroma and appearance score of cassava flour produced using a fixed-bed dryer and a pneumatic dryer in Ghana.

\begin{tabular}{ccccc}
\hline Dryer Type & Whiteness Index & Lightness & Chroma & Appearance Score \\
\hline Fixed-bed & $41.2^{\mathrm{a}} \pm 1.6$ & $89.3^{\mathrm{a}} \pm 0.9$ & $7.0^{\mathrm{a}} \pm 0.6$ & $6.1^{\mathrm{a}} \pm 0.6$ \\
Pneumatic & $37.0^{\mathrm{b}} \pm 3.2$ & $88.9^{\mathrm{a}} \pm 1.4$ & $7.7^{\mathrm{a}} \pm 0.4$ & $6.1^{\mathrm{a}} \pm 1.0$ \\
\hline
\end{tabular}

Means with no common superscript letter are significantly different by Fisher's Least Significant Difference test at $5 \%$ level of significance $(\alpha=0.05)$.

Regarding lightness and chroma, Table 4 shows no significant differences between the flours from each dryer were observed, despite the significant differences in the Whiteness Index. A product of white colour has a high $L^{*}$ and a low $C^{*}$ [67]. For both dryers, $L^{*}$ were inferior to the values presented by Precoppe, Tran, Chapuis, Müller and Abass [54] on pneumatically dried cassava, but still above the threshold suggested by Neves, Neves, Lobato, Nascimento and Clerici [57] for consumers acceptance. Regarding $C^{*}$, only the cassava flour obtained from the fixed-bed dryer was below the chroma calculated from the values $a^{*}$ and $b^{*}$ reported by Precoppe, Tran, Chapuis, Müller and Abass [54].

Regarding appearance score, Table 4 shows that staff members responsible for controlling product quality at the processing enterprise were not able to observe visual differences between the cassava flour obtained from each dryer, suggesting that the product would be equally accepted by consumers, despite the significant differences in WI.

\subsection{Costs Comparison}

Table 5 shows the differences in the components of the operating costs, using the fixed-bed dryer as a reference. Regarding fuel consumption, the fixed-bed dryer used $5.3 \pm 0.3 \mathrm{~kg} \mathrm{~h}^{-1}$, while the pneumatic dryer used $2.8 \pm 0.5 \mathrm{~kg} \mathrm{~h}^{-1}$, the difference being significant by the LSD test at $5 \%$ level of significance. Both dryers had similar heating units, therefore, the greater fuel consumption of the fixed-bed dryer can be explained by its higher heat input rate. To produce $1 \mathrm{~kg}$ of dried solid the fixed-bed dryer consumed $0.11 \pm 0.01 \mathrm{~kg}$ and the pneumatic dryer consumed $0.07 \pm 0.02 \mathrm{~kg}$, being significantly different by the LSD test at $5 \%$ level of significance. Considering the cost of the diesel, to produce $1 \mathrm{~kg}$ of dried cassava grit, USD 0.14 was spent when the fixed-bed dryer was used and USD 0.08 was spent when the pneumatic dryer was used.

Table 5. Fixed-bed dryer and pneumatic dryer differences in operating costs.

\begin{tabular}{ccc}
\hline Operating Costs & $\begin{array}{c}\text { Relative Difference from the } \\
\text { Fixed-Bed Dryer (USD kg } \mathbf{~ k}^{-\mathbf{1}} \text { ) }\end{array}$ & $\begin{array}{c}\text { Percentage Difference from the } \\
\text { Fixed-Bed Dryer (\%) }\end{array}$ \\
\hline Fuel & -0.060 & -42.9 \\
Electric power & +0.005 & +25.0 \\
Labour & 0.000 & 0.0 \\
Maintenance & 0.000 & 0.0 \\
\hline
\end{tabular}

Regarding the electric power consumption, the fixed-bed dryer used $1.3 \pm 0.1 \mathrm{~kW}$ while the pneumatic dryer used $2.3 \pm 0.2 \mathrm{~kW}$, this difference is significant by the LSD test at $5 \%$ level of significance. While the fixed-bed dryer had only one $5.2 \mathrm{~kW}$ motor powering the fan, the pneumatic dryer had two, a $4.0 \mathrm{~kW}$ motor powering the feeder and another $7.5 \mathrm{~kW}$ motor powering the fan, explaining the higher electric power consumption observed in this dryer. As noted, the air mass flow rate in the fixed-bed dryer was significantly higher, but the motor powering the fan was of a smaller size. That is because, in the pneumatic dryers, the airflow has not only to remove the evaporated moisture but has also to provide the required hydrodynamic condition needed to transport the material. According to Kudra et al. [68], in general, fuel to supply the dryer with heat is the main component of operating costs, however, for dryers with specific hydrodynamic requirements, costs with electricity can also become an important component. For both dryers, electric power consumption was higher 
than the values reported by Precoppe, Tran, Chapuis, Müller and Abass [54] on pneumatic drying of cassava, suggesting less efficient fan design. To produce $1 \mathrm{~kg}$ of dried cassava grits, the fixed-bed dryer consumed $25.1 \pm 0.2 \mathrm{~W}$ of electric power and the pneumatic dryer consumed $57.4 \pm 14.8 \mathrm{~W}$, the difference being significant by the LSD test at $5 \%$ level of significance. Considering the cost of electricity, to produce $1 \mathrm{~kg}$ of dried cassava grits, USD 0.004 was spent when the fixed-bed dryer was used and USD 0.009 was spent when the pneumatic dryer was used.

Regarding labour, the fixed-bed dryer and the pneumatic dryer had very distinct working regimes. The fixed-bed dryer demanded intense work during loading and unloading plus when moving and turning the product during drying. The workload of the pneumatic dryer did not have those peaks and was rather steady over time. Nevertheless, the processing enterprise employed one person to operate each dryer, working in an $8 \mathrm{~h}$ shift. Therefore, despite the different working regimes, no difference in labour costs for each dryer was observed.

Regarding maintenance cost, it is known to be low in fixed-bed dryers and pneumatic dryers due to the few numbers of moving parts [11]. The enterprise spending logbook had revealed that the fixed-bed dryer and the pneumatic dryer were inspected at the same intervals and for both, the maintenance included servicing the diesel burner and replacing the bearings that hold the shaft of the fan. Therefore, no difference in maintenance costs for each dryer was observed.

Regarding capital cost, based on the equipment manufacturer contacted, the cost of the fixed-bed dryer used in this study was approximately USD 4000. In contrast, the cost of the pneumatic dryer was approximately USD 7300. Fixed-bed dryers are well known for having low capital cost [46]. As a result of the lower operating costs of the pneumatic dryer, the additional investment could be recovered in 194 days of operation. However, the sensitivity analysis, shown in Figure 7, indicates that the payback period is highly sensitive to variations in diesel and electricity prices. It reduces if the diesel prices rise (Figure 7a) and it increases if electricity prices rise (Figure 7b).

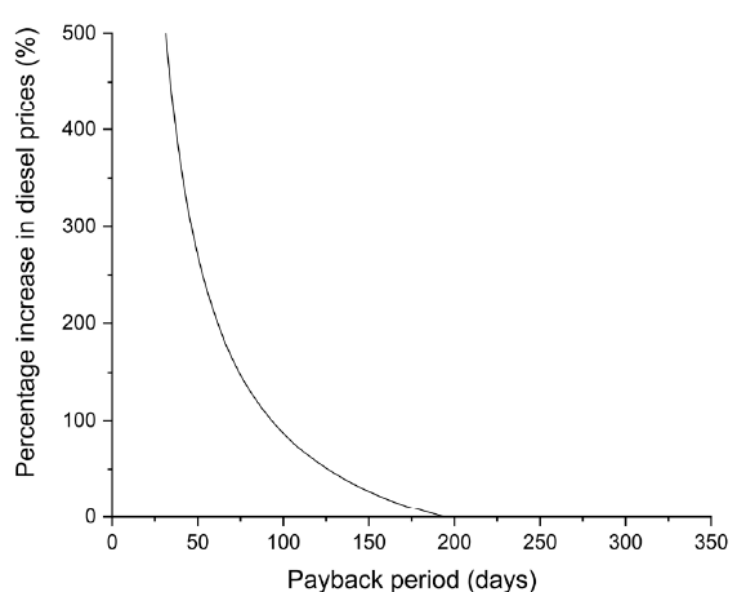

(a)

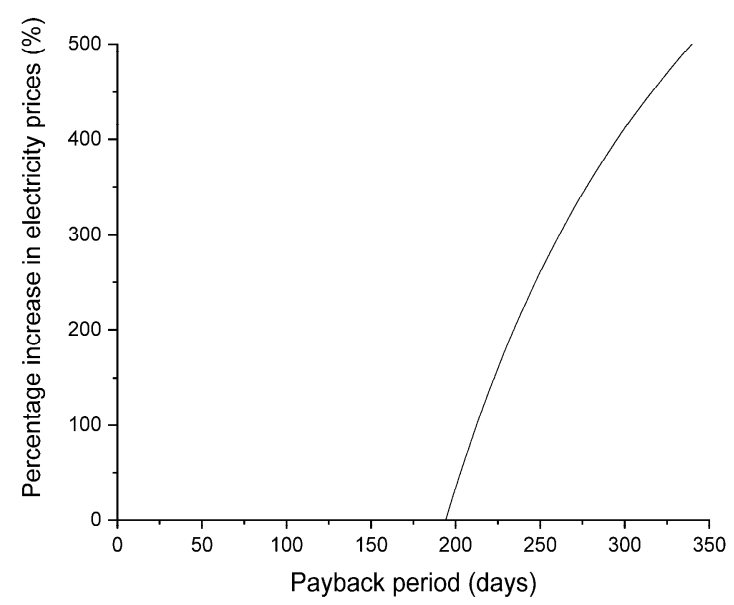

(b)

Figure 7. Sensitivity analysis showing the influence of (a) diesel price and (b) electricity price in the pneumatic dryer payback period.

\section{Conclusions}

This study demonstrated that for processing cassava grits, the pneumatic dryer was more energy efficient than the fixed-bed dryer. However, the Whiteness Index of the flour produced by the fixed-bed dryer was higher, but the other colour parameters were not significantly different. In addition, the staff controlling product quality could not distinguish flours produced by each dryer. This led us to conclude that consumers would equally accept both products. Regarding costs, the pneumatic dryer had a higher capital cost but a lower operating cost, and to recover the additional investment made for this dryer, a short amount of time was needed. Therefore, this comparative study allows us to conclude that 
the pneumatic dryer is a better choice of equipment for cassava processing by small-size enterprises in Africa, and for this reason, we recommend that this should be the type of dryer promoted and disseminated by policymakers and researchers working on rural development.

Author Contributions: Conceptualization, M.P., A.C. and J.M.; methodology, M.P.; data collection, M.P. and G.A.K.; laboratory analysis, G.A.K.; data analysis, M.P. and A.C.; writing, M.P.; artwork, M.P.; supervision, J.M.; project administration, M.P.; funding acquisition, M.P. All authors have read and agreed to the published version of the manuscript.

Funding: This research was funded by the CGIAR Research Program on Roots, Tubers and Bananas (RTB).

Acknowledgments: Gratitude should be expressed to Tropical Starch Company Limited for taking part in the research. We would also like to thank Thierry Tran for his helpful suggestions during the writing of this paper.

Conflicts of Interest: The authors declare no conflict of interest and the funder had no role in the design of the study; in the collection, analyses, or interpretation of data; in the writing of the manuscript, or in the decision to publish the results.

\section{References}

1. Allem, A.C. The origins and taxonomy of cassava. In Cassava: Biology, Production and Utilization; Hillocks, R.J., Thresh, J.M., Bellotti, A., Eds.; CABI: Wallingford, UK, 2002; pp. 1-16.

2. Balagopalan, C. Cassava utilization in food, feed and industry. In Cassava: Biology, Production and Utilization; Hillocks, R.J., Thresh, J.M., Bellotti, A., Eds.; CABI: Wallingford, UK, 2002; pp. 301-318.

3. Hillocks, R.J. Cassava in Africa. In Cassava: Biology, Production and Utilization; Hillocks, R.J., Thresh, J.M., Bellotti, A., Eds.; CABI: Wallingford, UK, 2002; pp. 41-54.

4. Westby, A. Cassava utilization, storage and small-scale processing. In Cassava: Biology, Production and Utilization; Hillocks, R.J., Thresh, J.M., Bellotti, A., Eds.; CABI: Wallingford, UK, 2002; pp. 281-300.

5. Breuninger, W.F.; Piyachomkwan, K.; Sriroth, K. Tapioca/cassava starch: Production and use. In Starch: Chemistry and Technology, 3rd ed.; BeMiller, J., Whistler, R., Eds.; Academic Press: San Diego, CA, USA, 2009; pp. 541-568. [CrossRef]

6. Lebot, V. Tropical root and tuber crops: Cassava, sweet potato, yams and aroids; CABI: Wallingford, UK, 2009; Volume 17, 433p.

7. Precoppe, M.; Chapuis, A.; Müller, J.; Abass, A. Tunnel dryer and pneumatic dryer performance evaluation to improve small-scale cassava processing in Tanzania. J. Food Process. Eng. 2017, 40, 1-10. [CrossRef]

8. Chua, K.J.; Chou, S.K. Low-cost drying methods for developing countries. Trends Food Sci. Technol. 2003, 14, 519-528. [CrossRef]

9. Saravacos, G.; Kostaropoulos, A.E. Food evaporation equipment. In Handbook of Food Processing Equipment, 2nd ed.; Springer: Cham, Switzerland, 2016; pp. 367-419. [CrossRef]

10. Proctor, D.L. Grain Storage Techniques: Evolution and Trends in Developing Countries; Food and Agriculture Organization of the United Nations (FAO): Rome, Italy, 1994.

11. Mujumdar, A.S. Drying: Principles and practice. In Albright's Chemical Engineering Handbook; Albright, L.F., Ed.; CRC Press: Boca Raton, FL, USA, 2008; pp. 1667-1716. [CrossRef]

12. Vijayan, S.; Arjunan, T.V.; Kumar, A. Fundamental concepts of drying. In Solar Drying Technology: Concept, Design, Testing, Modeling, Economics, and Environment; Prakash, O., Kumar, A., Eds.; Springer: Singapore, 2017; pp. 3-38. [CrossRef]

13. Berk, Z. Food Process Engineering and Technology, 3rd ed.; Academic Press: London, UK, 2018; 743p. [CrossRef]

14. Driscoll, R. Food dehydration. In Food Processing: Principles and Applications; Smith, J.S., Hui, Y.H., Eds.; Blackwell: Ames, IA, USA, 2008; pp. 31-44. [CrossRef]

15. Müller, J.; Mühlbauer, W. Solar drying. In Modern Drying Technology: Energy Savings; Tsotsas, E., Mujumdar, A.S., Eds.; Wiley-VCH: Weinheim, Germany, 2012; Volume 4, pp. 199-243.

16. Román, F.; Strahl-Schäfer, V.; Hensel, O. Improvement of air distribution in a fixed-bed dryer using computational fluid dynamics. Biosyst. Eng. 2012, 112, 359-369. [CrossRef]

17. Scaar, H.; Teodorov, T.; Ziegler, T.; Mellmann, J. Computational fluid dynamics (CFD) analysis of air flow uniformity in a fixed-bed dryer for medicinal plants. Acta Hortic. 2013, 1008, 119-126. [CrossRef] 
18. Nagle, M.; González-Azcárraga, J.C.; Phupaichitkun, S.; Mahayothee, B.; Haewsungcharern, M.; Janjai, S.; Leis, H.; Müller, J. Effects of operating practices on performance of a fixed-bed convection dryer and quality of dried longan. Int. J. Food Sci. Technol. 2008, 43, 1979-1987. [CrossRef]

19. Nagle, M.; González Azcárraga, J.C.; Mahayothee, B.; Haewsungcharern, M.; Janjai, S.; Müller, J. Improved quality and energy performance of a fixed-bed longan dryer by thermodynamic modifications. J. Food Eng. 2010, 99, 392-399. [CrossRef]

20. Ziegler, T.; Jubaer, H.; Schütz, M. Increasing the Energy Efficiency of Batch-Type Drying with Partial Air Recirculation. Chem. Ing. Tech. 2016, 88, 208-214. [CrossRef]

21. Markowski, A.S.; Mujumdar, A.S. Safety aspects of industrial dryers. In Handbook of Industrial Drying, 4th ed.; Mujumdar, A.S., Ed.; CRC Press: Boca Raton, FL, USA, 2014; pp. 1127-1151. [CrossRef]

22. Nimmol, C. Performance, energy, and product quality aspects of a modified pneumatic dryer for rapid drying of high-moisture paddy. Trans. ASABE 2019, 62, 1531-1539. [CrossRef]

23. Banooni, S.; Hajidavalloo, E.; Dorfeshan, M. A comprehensive review on modeling of pneumatic and flash drying. Dry. Technol. 2018, 36, 33-51. [CrossRef]

24. Ziegler, T. Primary energy demand and energy costs of fixed-bed drying using the example of chamomile flowers. Dry. Technol. 2020, 38, 434-447. [CrossRef]

25. Yi, J.; Li, X.; He, J.; Duan, X. Drying efficiency and product quality of biomass drying: A review. Dry. Technol. 2019. [CrossRef]

26. Nimmol, C.; Sathapornprasath, K.; Devahastin, S. Drying of High-Moisture Paddy Using a Combined Impinging Stream and Pneumatic Drying System. Dry. Technol. 2012, 30, 1854-1862. [CrossRef]

27. Ziegler, T.; Mellmann, J. Thermodynamic interactions in a fixed bed drying process using heat pumps-Fundamentals and implementation. Z. Arznei Gewurzpflanzen 2008, 13, 167-172.

28. Santos, P.; Pitarch, J.L.; Vicente, A.; de Prada, C.; García, Á. Improving operation in an industrial MDF flash dryer through physics-based NMPC. Control. Eng. Pract. 2020, 94. [CrossRef]

29. Pakowski, Z.; Mujumdar, A.S. Drying of pharmaceutical products. In Handbook of Industrial Drying, 4th ed.; Mujumdar, A.S., Ed.; CRC Press: Boca Raton, FL, USA, 2014; pp. 681-701. [CrossRef]

30. Kudra, T. Energy aspect in food dehydration. In Advances in Food Dehydration; Ratti, C., Ed.; CRC Press: Boca Raton, FL, USA, 2009; pp. 423-445.

31. Aghbashlo, M.; Kianmehr, M.H.; Arabhosseini, A. Energy and exergy analyses of thin-layer drying of potato slices in a semi-industrial continuous band dryer. Dry. Technol. 2008, 26, 1501-1508. [CrossRef]

32. Bonazzi, C.; Broyart, B.; Courtois, F. Dryer modeling. In Advances in Food Dehydration; Ratti, C., Ed.; CRC Press: Boca Raton, FL, USA, 2009; pp. 355-399.

33. Laverde, L.M.A.; Acevedo, N.; Schebor, C.; Buera, M.D.P. Color determination in dehydrated fruits: Image analysis and photocolorimetry. In Color in Food; Caivano, J., del Pilar Buera, M., Eds.; CRC Press: Boca Raton, FL, USA, 2012; pp. 155-162.

34. Jinorose, M.; Devahastin, S.; Blacher, S.; Léonard, A. Application of image analysis in food drying. In Advances in Food Dehydration; Ratti, C., Ed.; CRC Press: Boca Raton, FL, USA, 2009; pp. 63-94.

35. Caivano, J.L.; Buera, M.d.P. Food appearance and expectations. In Color in Food: Technological and Psychophysical Aspects; Caivano, J., del Pilar Buera, M., Eds.; CRC Press: Boca Raton, FL, USA, 2012; pp. 3-9.

36. Acevedo, N.C.; Briones, V.; Buera, P.; Aguilera, J.M. Microstructure affects the rate of chemical, physical and color changes during storage of dried apple discs. J. Food Eng. 2008, 85, 222-231. [CrossRef]

37. Clark, J.P. Cost and profitability estimation. In Handbook of Food Engineering Practice; Valentas, K.J., Rotstein, E., Singh, R.P., Eds.; CRC Press: Boca Raton, FL, USA, 1997; pp. 530-550.

38. Crapiste, G.H.; Rotstein, E. Design and performance evaluation of dryers. In Handbook of Food Engineering Practice; Valentas, K.J., Singh, R.P., Rotstein, E., Eds.; CRC Press: Boca Raton, FL, USA, 1997; pp. 121-162. [CrossRef]

39. AOAC. Moisture in malt (method 935.29). In Official Methods of Analysis; Association of Official Analytical Chemists (AOAC): Gaithersburg, MD, USA, 1998.

40. ASHRAE. ANSI/ASHRAE Standard 111-2008: Measurement, Testing, Adjusting, and Balancing of Building HVAC Systems; American Society of Heating, Refrigerating and Air-Conditioning Engineers: Atlanta, GA, USA, 2008.

41. British Standard. Guide to the Measurement of Humidity; (Standard BS 1339-3:2004); British Standards Institution: London, UK, 2004; 40p. 
42. Al-Muhtaseb, A.H.; McMinn, W.A.M.; Magee, T.R.A. Water sorption isotherms of starch powders: Mathematical description of experimental data. J. Food Eng. 2004, 61, 297-307. [CrossRef]

43. Moskowitz, H.R.; Beckley, J.H.; Resurreccion, A.V.A. Sensory and Consumer Research in Food Product Design and Development, 2nd ed.; Blackwell: Oxford, UK, 2012. [CrossRef]

44. CIE. Colorimetry (CIE Publication 15.2); Commission Internationale de l'Eclairage (CIE) Central Bureau: Vienna, Austria, 2004; 79p.

45. Judd, D.B.; Wyszecki, G. Color in Business, Science, and Industry; John Wiley \& Sons: New York, NY, USA, 1975. [CrossRef]

46. Fellows, P.J. Food Processing Technology: Principles and Practice, 4th ed.; Woodhead: London, UK, $2017 ;$ p. 1152. [CrossRef]

47. Jayaraman, K.S.; Gopinathan, V.K.; Pitchamuthu, P.; Vijayaraghavan, P.K. The preparation of quick-cooking dehydrated vegetables by high temperature short time pneumatic drying. Int. J. Food Sci. Technol. 1982, 17, 669-678. [CrossRef]

48. Mujumdar, A.S.; Jangam, S.V.; Pikon, J. Drying of coal. In Handbook of Industrial Drying, 4th ed.; Mujumdar, A.S., Ed.; CRC Press: Boca Raton, FL, USA, 2014; pp. 999-1022.

49. Nimmol, C.; Yodrux, A.; Hirunwat, A. Rapid drying of high-moisture paddy using a pneumatic dryer with corrugated-surface drying column. E3s Web Conf. 2020, 141, 1-5. [CrossRef]

50. Suherman, K.; Cahyo, A.; Kusworo, T.D. Experimental study on drying kinetic of cassava starch in a pneumatic drying system. Int. Conf. Chem. Mater. Eng. ICCME 2015, 1699, 1-6. [CrossRef]

51. Aviara, N.A.; Onuoha, L.N.; Falola, O.E.; Igbeka, J.C. Energy and exergy analyses of native cassava starch drying in a tray dryer. Energy 2014, 73, 809-817. [CrossRef]

52. Sablani, S.S.; Mujumdar, A.S. Drying of potato, sweet potato, and other roots. In Handbook of Industrial Drying, 4th ed.; Mujumdar, A.S., Ed.; CRC Press: Boca Raton, FL, USA, 2014; pp. 647-660.

53. Block, B.; Lipták, B.G.; Shinskey, F.G. Dryer controls. In Instrument Engineers' Handbook: Process Control and Optimization, 4th ed.; Lipták, B., Ed.; CRC Press: Stamford, CN, USA, 2005; Volume 2, pp. 1904-1913.

54. Precoppe, M.; Tran, T.; Chapuis, A.; Müller, J.; Abass, A. Improved energy performance of small-scale pneumatic dryers used for processing cassava in Africa. Biosyst. Eng. 2016, 151, 510-519. [CrossRef]

55. Skjöldebrand, C. Food-processing equipment. In Handbook of Food Factory Design; Baker, C.G.J., Ed.; Springer: New York, NY, USA, 2013; pp. 51-77. [CrossRef]

56. Shittu, T.A.; Alimi, B.A.; Wahab, B.; Sanni, L.O.; Abass, A.B. Cassava flour and starch: Processing technology and utilization. In Tropical Roots and Tubers; Sharma, H.K., Njintang, N.Y., Singhal, R.S., Kaushal, P., Eds.; John Wiley \& Sons: Chichester, UK, 2016; pp. 415-450. [CrossRef]

57. Neves, E.C.A.; Neves, D.A.; Lobato, K.B.d.S.; Nascimento, G.C.d.; Clerici, M.T.P.S. Technological aspects of processing of cassava derivatives. In Handbook on Cassava: Production, Potential Uses and Recent Advances; Klein, C., Ed.; Nova Science Publishers: New York, NY, USA, 2017; pp. 105-127.

58. Schlünder, E.U.; Spalding, D.B.; Taborek, J. Heat Exchanger Design Handbook; VDI: Dusseldorf, Germany, 1987.

59. Strumiłło, C.; Jones, P.L.; Żyłła, R. Energy aspects in drying. In Handbook of Industrial Drying, 4th ed.; Mujumdar, A.S., Ed.; CRC Press: Boca Raton, FL, USA, 2014; pp. 1077-1100. [CrossRef]

60. Azadbakht, M.; Aghili, H.; Ziaratban, A.; Torshizi, M.V. Application of artificial neural network method to exergy and energy analyses of fluidized bed dryer for potato cubes. Energy 2017, 120, 947-958. [CrossRef]

61. Chapuis, A.; Precoppe, M.; Méot, J.M.; Sriroth, K.; Tran, T. Pneumatic drying of cassava starch: Numerical analysis and guidelines for the design of efficient small-scale dryers. Dry. Technol. 2017, 35, 393-408. [CrossRef]

62. Sriroth, K.; Piyachomkwan, K.; Wanlapatit, S.; Oates, C.G. Cassava starch technology: The Thai experience. Starch Stärke 2000, 52, 439-449. [CrossRef]

63. Kemp, I.C. Fundamentals of energy analysis of dryers. In Modern Drying Technology: Energy Savings; Tsotsas, E., Mujumdar, A.S., Eds.; Wiley-VCH: Weinheim, Germany, 2012; Volume 4, pp. 1-45.

64. Prukwarun, W.; Khumchoo, W.; Seancotr, W.; Phupaichitkun, S. CFD simulation of fixed bed dryer by using porous media concepts: Unpeeled longan case. Int. J. Agric. Biol. Eng. 2013, 6, 100-110. [CrossRef]

65. Ramsey, T.; Fortis, T. Improving the air flow distribution in a batch walnut dryer. Trans. ASAE 1984, 27, 938-941. [CrossRef]

66. Satpati, B.; Koley, C.; Datta, S. Nonlinear model of pneumatic conveying dryer for economic process control. Dry. Technol. 2019, 1-22. [CrossRef] 
67. Smith, K.J. Colour-order systems, colour spaces, colour difference and colour scales. In Colour Physics for Industry, 2nd ed.; McDonald, R., Ed.; Society of Dyers and Colourists: Bradford, UK, 1997; pp. 121-208.

68. Kudra, T.; Platon, R.; Navarri, P. Excel-based tool to analyze the energy performance of convective dryers. Dry. Technol. 2009, 27, 1302-1308. [CrossRef]

Publisher's Note: MDPI stays neutral with regard to jurisdictional claims in published maps and institutional affiliations.

(C) 2020 by the authors. Licensee MDPI, Basel, Switzerland. This article is an open access article distributed under the terms and conditions of the Creative Commons Attribution (CC BY) license (http://creativecommons.org/licenses/by/4.0/). 